\title{
Extreme Methane Bubbling Emissions from a Subtropical Shallow Eutrophic Pond
}

\author{
Shangbin Xiao ${ }^{1,2 *}$, Weiguo Liu', Hong Yang ${ }^{3}$, Defu \\ Liu $^{4}$, Yuchun Wang 5 , Feng Peng', Yingchen Li $^{2}$, \\ Chenghao Wang', Cheng Zhang' ${ }^{2}$, Xianglong $\mathrm{Li}^{2}$, \\ Gaochang $\mathrm{Wu}^{2}$, Li Liu ${ }^{2}$ and Kaihua Ouyang ${ }^{2}$ \\ Institute of Earth Environment, Chinese Academy of \\ Sciences, Xi'an 710075, China \\ ${ }^{2}$ College of Hydraulic \& Environmental Engineering, \\ China Three Gorges University, Yichang, 443002, China \\ ${ }^{3}$ Bryant University, Smithfield RI, 02917, USA; \\ ${ }^{4}$ College of Resources and Environment Sciences, Hubei \\ University of Technology, Wuhan, 430068, China \\ ${ }^{5}$ Department of Water Environment, China Institute of \\ Water Resources and Hydropower Research, Beijing, \\ 100038, China \\ *Corresponding author: Shangbin XIAO, Institute of \\ Earth Environment, Chinese Academy of Sciences, Xi'an \\ 10075, China
}

Received: September 29, 2014; Accepted: October 27, 2014; Published: November 01, 2014

\begin{abstract}
For the first time we report on real time diel bubble and diffusion gas fluxes lasting for 48 hours of a subtropical shallow pond. The averaged diffusion fluxes of methane and carbon dioxide were 0.074 and $62.70 \mathrm{mg} \cdot \mathrm{m}^{-2} \cdot \mathrm{h}^{-1}$, and the averaged ebullition fluxes of methane and carbon dioxide were 24.726 and $1.92 \mathrm{mg} \cdot \mathrm{m}^{-2} \cdot \mathrm{h}^{-1}$ respectively. Bubble emissions of $\mathrm{CH}_{4}$ and $\mathrm{CO}_{2}$ accounted for $99.7 \%$ of the total $\mathrm{CH}_{4}$ emission and only $3.0 \%$ of the total $\mathrm{CO}_{2}$ from the pond respectively. The $\mathrm{CH}_{4}$ flux across the water-air interface of the pond was 595.20

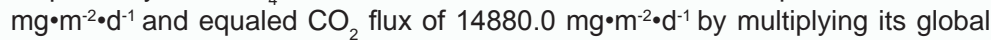
warming potential. Thus, the small pond added equivalent of $35.712 \mathrm{~kg} / \mathrm{d} \mathrm{CO}_{2}$ emission by transferring $\mathrm{CO}_{2}$ to $\mathrm{CH}_{4}$ in the summer, in which process $\mathrm{CO}_{2}$ was absorbed owing to alga propagation and $\mathrm{CH}_{4}$ emission was derived from the anaerobic degradation of dead alga buried on its bottom.
\end{abstract} Pond

Keywords: Methane; Carbon dioxide; Bubbling efflux; Diffusion; Eutrophic;

\section{Introduction}

Freshwaters can be substantial sources of $\mathrm{CO}_{2}$ and $\mathrm{CH}_{4}$ [1-3]. Lakes, ponds, and impoundments cover $3 \%$ of the earth's surface. Of them, natural lakes and ponds are estimated to cover about $4.2 \times 10^{6}$ $\mathrm{km}^{2}$, whereas impoundments cover $2.6 \times 10^{5} \mathrm{~km}^{2}$, and farm ponds cover about $7.7 \times 10^{4} \mathrm{~km}^{2}$ [4]. Greenhouse gases emitted from lakes and reservoirs received respective attention [5-10]. However, less attention was paid to ponds, which are small in area and relatively shallow in depth but with various physical geographical characteristics and eutrophic situation. The importance of small lakes and ponds in the global lake area/number and in the global carbon cycle might have been underestimated $[2,4,11]$. Small wetland lakes and ponds that are often abundant in peat land areas can have high $\mathrm{CO}_{2}$ and $\mathrm{CH}_{4}$ emissions [12,13]. Moreover, it has been shown that the small areas of high $\mathrm{CH}_{4}$ emissions, such as wetland ponds, can largely contribute to the landscape-scale $\mathrm{CH}_{4}$ budgets in wetland regions and create a major uncertainty in the areal $\mathrm{CH}_{4}$ emission estimates [14].

The rotation of the earth results in diel biogeochemical cycles, which are in response to the solar photocycle, particularly during stable hydrological conditions [15]. The amplitude of some of these diel changes can be as large as the changes occurring on annual timescales [15]. However, reports about gas fluxes on the diel timescale are scarce compared to those on the seasonal timescale. The former has received attention only more recently. To date, most reported gas ebullition rates were measured with bubble collectors [16-19], which could represent an average flux rate of a long monitoring period. No report could be found about the real-time gas ebullition emission. Study of diel variations is helpful to reveal which biogeochemical processes occur relatively rapidly in natural waters, and therefore which processes play an integral and important role in the normal functioning of natural water systems [15]. Data of diel greenhouse gas fluxes reported previously were at intervals of 3-4 h [20,21], and not continuous. Here, for the first time we present data of greenhouse gas flux from a field campaign lasting for 48 hours in the summer of 2013 regarding a subtropical hypertrophic pond. We hope the real time results can give some knowledge for recognizing the greenhouse gases emitting from small and shallow ponds both by ebullition and by diffusion.

\section{Materials and Methods}

\section{Study area and monitoring sites}

The pond $\left(111^{\circ} 20^{\prime} 50.16^{\prime \prime} \mathrm{E}, 30^{\circ} 44^{\prime} 30.978^{\prime \prime} \mathrm{N}\right)$ is located at a suburban district of Yichang city, Hubei province, Central China. Yichang city is of a subtropical continental monsoon climate with a largely changing temperature in the spring, heavy rain and drought in the summer, wet weather in autumn and humid and snowy weather in the winter. The average annual temperature is $16.9^{\circ} \mathrm{C}$, and the average rainfall is $1215.6 \mathrm{~mm}$. The pond is about $2,500 \mathrm{~m}^{2}$ with a maximum and mean water depth of 2.5 and $1.5 \mathrm{~m}$ respectively. It is surrounded by a small, locally known restaurant, and is a popular fishing area. The total nitrogen and phosphorus concentrations in waters are about 0.067 and $0.020 \mathrm{mg} / \mathrm{L}$ respectively. The pound bottom is covered with soft organic sediments (the total organic carbon content is $27.92 \mathrm{mg} / \mathrm{g}$ ). The waters appeared green color owing to a great deal of the growing algae(mainly Fragilaria, Scenedesmus quadricanda, and Oocystis). We carried out diel flux measuring at two sites, which are 2 and $5 \mathrm{~m}$ away from its bank, and with depths of 1.2 and $1.5 \mathrm{~m}$ respectively (here marked as Site $\mathrm{N}$ and F). The field campaign lasted 48 hours from July 22 to 24,2013 . Here, we only report the results of Site $\mathrm{N}$ because of its representative water depth and location.
Austin Biom and Biostat - Volume 1 Issue 2 - 2014

Submit your Manuscript | www.austinpublishinggroup.com

Xiao et al. ( ) All rights are reserved
Citation: Xiao S, Liu W, Yang H, Liu D, Wang Y, Peng F, et al. Extreme Methane Bubbling Emissions from a Subtropical Shallow Eutrophic Pond. Austin Biom and Biostat. 2014;1(2): 6. 


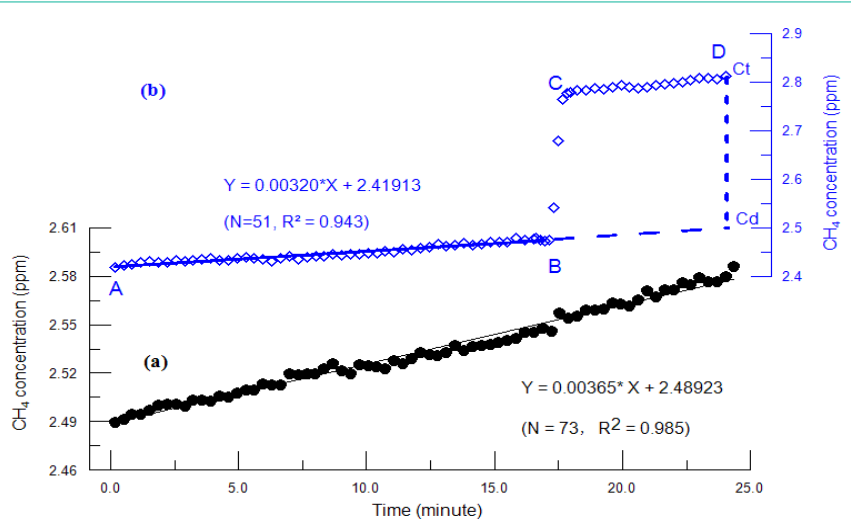

Figure 1: Curve Patterns of Changes in $\mathrm{CH}_{4}$ concentration without bubble (a) and with bubble (b) during a single flux monitoring period.

\section{In situ sampling measurements and analysis}

Surface and bottom water temperature ( $\mathrm{Ts}$ and $\mathrm{Tb}$ ), $\mathrm{pH}$, air temperature $(\mathrm{Ta})$, air pressure $(\mathrm{Pa})$, intensity of illumination (Ii) and wind speed (Swi) were measured at the sites. Water temperature, the $\mathrm{pH}$ of water, and dissolved oxygen concentration (DO) in water were measured using the multi-parameter instrument Orion Star A329 (the United States). Water samples were taken from depths of $0.1 \mathrm{~m}$ below the water surface and $0.1 \mathrm{~m}$ above the bottom respectively for analysis of chlorophyll a concentration (Chl-a), and dissolved $\mathrm{CH}_{4}$ and $\mathrm{CO}_{2}$. Water samples $(350 \mathrm{~mL})$ were collected and transported to the laboratory for Chl-a analysis using the national standard method [22]. A headspace equilibration technique was used to quantify dissolved gas concentrations in water, and dissolved gas concentration in water is calculated according to the equation given by Johnson et al. [23].

\section{Water-to-air fluxes}

A dynamic closed floating chamber system was used to measure diel $\mathrm{CH}_{4}$ and $\mathrm{CO}_{2}$ flux across the water-air interface. The chambers are non-transparent, thermally insulated tubes with a volume of $43.30 \mathrm{~L}$ and a surface area of $0.096 \mathrm{~m}^{2}$ (diameter and height are 0.35 and $0.45 \mathrm{~m}$ respectively). Fans inside the chambers were applied to obtain better mixing of the air inside the chamber headspace. When we measured the emission flux of $\mathrm{CH}_{4}$ and $\mathrm{CO}_{2}$ across the waterair interface, one chamber was connected to a Los Gatos Research's Greenhouse Gas Analyzer (DLT-100) (Los Gatos Research, USA), which could monitor the $\mathrm{CH}_{4}$ and $\mathrm{CO}_{2}$ concentration inside the chamber continuously with $1 \mathrm{~Hz}$ frequency. The DLT-100 is a cavity ring down spectrometer with high resolution $(0.1 \mathrm{ppb})$ and precision ( $1 \%$ of reading the accuracy) and was already described in detail and Table 1: Statistical description of main environmental factors.

\begin{tabular}{|c|c|c|c|c|c|c|c|c|c|c|c|c|}
\hline & \multirow{2}{*}{$\begin{array}{c}\mathrm{Ta} \\
\left({ }^{\circ} \mathrm{C}\right)\end{array}$} & \multirow{2}{*}{$\begin{array}{c}\mathrm{Pa} \\
(\mathrm{KPa})\end{array}$} & \multirow{2}{*}{$\begin{array}{l}\text { Swi } \\
(\mathrm{m} / \mathrm{s})\end{array}$} & \multirow{2}{*}{$\begin{array}{c}\mathrm{L} \\
(\operatorname{Lux})\end{array}$} & \multicolumn{2}{|c|}{$\begin{array}{l}\text { DO in water } \\
(\mathrm{mg} / \mathrm{L})\end{array}$} & \multicolumn{2}{|c|}{$\mathrm{pH}$ of water } & \multicolumn{2}{|c|}{$\begin{array}{l}\text { water temperature } \\
\qquad\left({ }^{\circ} \mathrm{C}\right)\end{array}$} & \multicolumn{2}{|c|}{ Chl-a (mg/L) } \\
\hline & & & & & DOs & $\mathrm{DOb}$ & $\mathrm{pH}-\mathrm{s}$ & $\mathrm{pH}-\mathrm{b}$ & Ts & $\mathrm{Tb}$ & Chl-as & Chl-ab \\
\hline Max & 37.1 & 98.97 & 0.99 & 78770 & 8.57 & 6.19 & 7.13 & 7.01 & 34.7 & 33.3 & 76.578 & 92.236 \\
\hline Min & 24.8 & 98.52 & 0 & 0 & 2.44 & 2.23 & 6.07 & 5.52 & 29.0 & 29.9 & 48.724 & 45.232 \\
\hline Average & 29.7 & 98.79 & 0.09 & 23412.88 & 5.02 & 3.99 & 6.60 & 6.63 & 31.1 & 31.1 & 60.021 & 64.640 \\
\hline Stdev & 3.65 & 0.11 & 0.23 & 29538.56 & 1.61 & 0.98 & 0.23 & 0.27 & 1.17 & 0.82 & 7.50 & 11.28 \\
\hline $\mathrm{CV}$ & 0.12 & 0.00 & 2.58 & 1.26 & 0.32 & 0.24 & 0.03 & 0.04 & 0.04 & 0.03 & 0.12 & 0.17 \\
\hline
\end{tabular}

Stdev: standard deviation; CV: coefficient of variation. Dos and DOb: dissolved oxygen concentration in surface and bottom water; $\mathrm{pHs}$ and $\mathrm{pHb}$ : $\mathrm{pH}$ of surface and bottom water; Ts and Tb: surface and bottom water temperature; Chl-as and Chl-ab: Chl-a concentration in surface and bottom water respectively. used by previous researchers [8,9,24-28]. A single flux measurement was usually finished in 30 minutes. The chamber was then taken off the water surface to ensure adequate exchanging and mixing between gas inside the chamber and the environmental air. A separate chamber at the other site was connected to the DLT-100 Analyzer to continue the flux measuring. Thus, we alternated between monitoring sites $\mathrm{N}$ and $\mathrm{F}$.

When there is no or little gas bubbles present in the chamber, concentrations of $\mathrm{CH}_{4}$ and $\mathrm{CO}_{2}$ gradually curve over time in a straight line due to the increase or decrease of gas concentrations in the chamber (Figurela). Under this situation, a simple linear regression method is used to calculate the releasing rate and the flux of gases, which was described in detail by Lambert and Fréchette [29]. The gas concentration in the chamber will increase abruptly when bubbling occurs (Figure1b). We can separate the bubble and diffusion flux with data acquired by the DLT-100 Analyzer thanks to its high sampling frequency (See the captions of Figure 1b) in (b): AB \& CDdiffusing, BC-bubbling. The equation $\left(\mathrm{Y}=0.00320^{*} \mathrm{X}+2.41913\right)$ is acquired by linear fitting based on data of $\mathrm{AB}$; $\mathrm{Ct}$ is the measured $\mathrm{CH}_{4}$ concentration at the monitored endpoint; $\mathrm{Cd}$ is the calculated $\mathrm{CH}_{4}$ concentration at the monitored endpoint according to the fitted equation; and the surplus $\mathrm{CH}_{4}$ concentration in the chamber resulted from bubble is equal to $\mathrm{Ct}$ minus $\mathrm{Cd}$. The figure above displays the calculated averages derived from original data. Each data point is derived from 20 individual data entries.

\section{Results}

\section{Variations in environmental factors}

During the monitoring period, air temperature experienced a large net change of $12.3{ }^{\circ} \mathrm{C}$ (Table 1). However, surface and bottom water temperature changed only 5.7 and $4.4^{\circ} \mathrm{C}$ respectively, and they showed a synchronal change (Figure 2). The differences between them were less than $2.0^{\circ} \mathrm{C}$ due to the shallow water depth at the site. Surface and bottom water temperature had a similar average value, and was greater than the averaged air temperature.

Most environmental factors except the wind speed, the DO content in bottom water, and the $\mathrm{pH}$ of water appeared obviously diel changes, which corresponded to the earth's evolution and the solar radiation (Figure 2). Significant correlations between them were observed here.

An excess of nutrients, hot weather and motionless water resulted the algal bloom in the pond (Figure 2 and Table 1). Chl-a concentration in surface water was significantly positively correlated with Ii, which indicated the dependence of photosynthesis on solar 


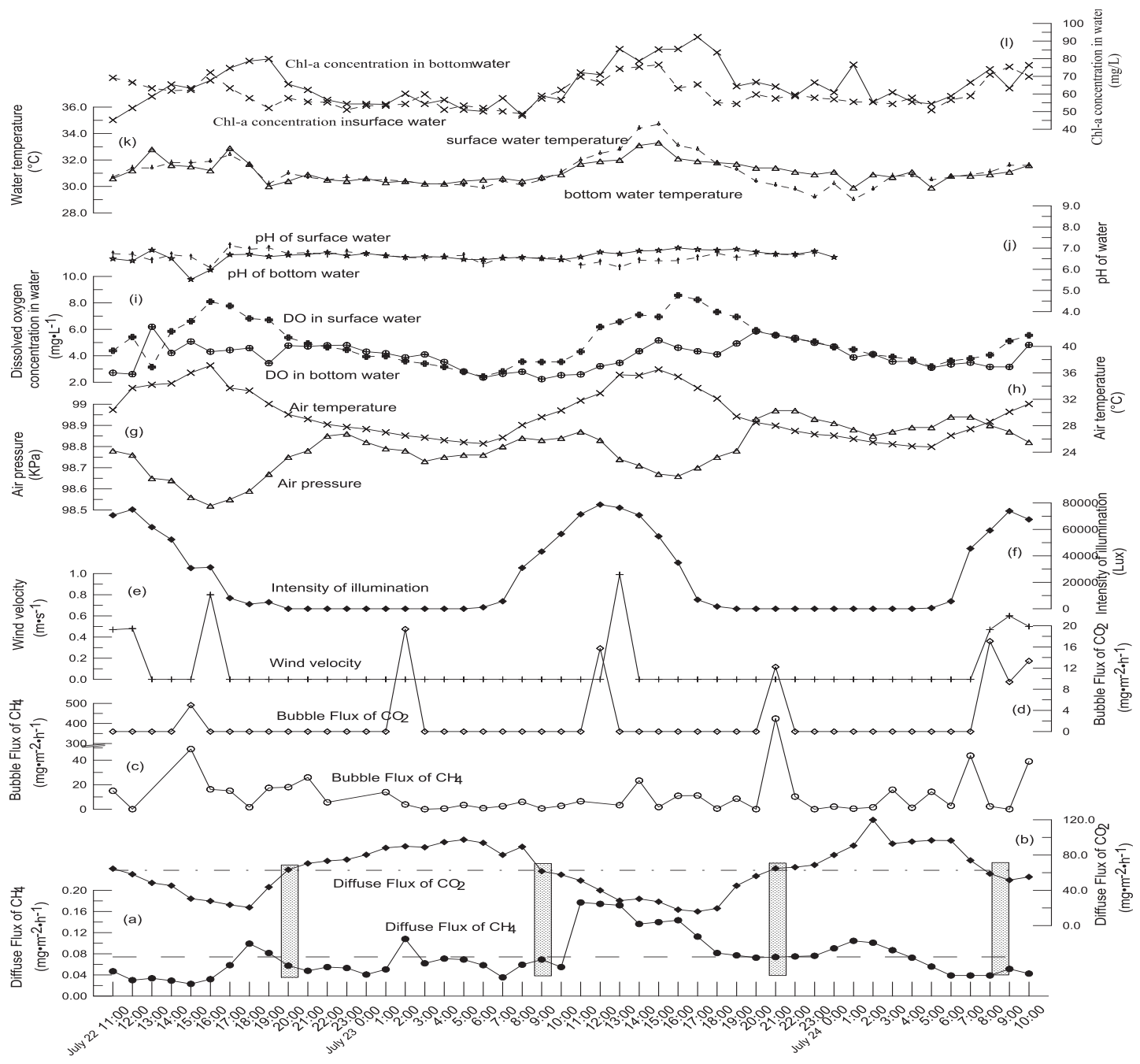

Figure 2: Diel $\mathrm{CH}_{4}$ and $\mathrm{CO}_{2}$ flux and environmental factors' changes during July 22-24, 2011in (a): dash-dotted and dashed lines represent the averaged die diffusive $\mathrm{CH}_{4}$ and $\mathrm{CO}_{2}$ fluxes.

radiation. DO in surface water showed the similar changing tendency with the Chl-a concentration in surface water which resulted from the alternative of phytoplankton respiration of algae (Figure 2). Wind speed had the biggest coefficient of variation of all environmental factors, which might result from obstruction of low speed wind from the surrounding buildings.

\section{Variations in diel $\mathrm{CH}_{4}$ and $\mathrm{CO}_{2}$ flux}

Both the diel diffusion $\mathrm{CH}_{4}$ and $\mathrm{CO}_{2}$ flux varied greatly during the monitoring period (Table 2). The diel diffusion $\mathrm{CO}_{2}$ flux showed obviously synchronal changes with air temperature and surface temperature. The diel diffusion $\mathrm{CH}_{4}$ flux fluctuated and changed gradually. The maximum values of diel diffusion $\mathrm{CH}_{4}$ and $\mathrm{CO}_{2}$ flux were 7.70 and 7.51 times of the respective minimum values. The natural variability of gas fluxes means that the number and time period of flux measurements is an important factor in obtaining an accurate average [30]. Here, the averaged values of both $\mathrm{CH}_{4}$ and $\mathrm{CO}_{2}$ flux occurred synchronously at around 9:00 and 20:00-21:00 of a day, which might give a referred time for single sampling when carrying out gas flux investigation in eutrophic water.

\section{$\mathrm{CH}_{4}$ and $\mathrm{CO}_{2}$ atmospheric fluxes}

Both total $\mathrm{CH}_{4}$ and $\mathrm{CO}_{2}$ fluxes across the water-air interface at Site F were very high, and were 595.20 and $1550.79 \mathrm{mg} \mathrm{m}^{-2} \bullet \mathrm{d}^{-1}$ respectively. The $\mathrm{CH}_{4}$ flux is 75.06 times of the overall average value across the water-air interface of the Three Gorges Reservoir [31] located in the same climate zone, and also much higher than the highest value $\left(\sim 150 \mathrm{mg} \bullet \mathrm{m}^{-2} \bullet \mathrm{d}^{-1}\right)$ of multitude reservoirs documented from Lake Wohlen, a run-of-river hydropower reservoir located in Switzerland [32].

Bubble emissions of $\mathrm{CH}_{4}$ accounted for $99.7 \%$ of the total $\mathrm{CH}_{4}$ emission, which implied that $\mathrm{CH}_{4}$ emitted into the air mainly through Table 2: Variation of diel $\mathrm{CH}_{4}$ and $\mathrm{CO}_{2}$ fluxes.

\begin{tabular}{|c|c|c|c|c|}
\hline & Diffusive- $\mathrm{CH}_{4}$ & Bubble- $\mathrm{CH}_{4}$ & Diffusive- $\mathrm{CO}_{2}$ & Bubble- $\mathrm{CO}_{2}$ \\
\hline $\begin{array}{c}\text { Maximum }(\mathrm{mg} \cdot \mathrm{m} \\
\left.\mathbf{2}^{-} \mathrm{h}^{-1}\right)\end{array}$ & 0.177 & 424.284 & 119.84 & 19.37 \\
\hline Minimum $\left(\mathrm{mg}^{\left.-\mathrm{m}^{-2} \cdot \mathrm{h}^{-1}\right)}\right.$ & 0.023 & 0.0 & 15.95 & 0.00 \\
\hline Average $\left(\mathrm{mg} \cdot \mathrm{m}^{-2} \cdot \mathrm{h}^{-1}\right)$ & 0.074 & 24.726 & 62.70 & 1.92 \\
\hline $\mathrm{Stdev}$ & 0.039 & 63.164 & 26.47 & 5.01 \\
\hline $\mathrm{CV}$ & 0.525 & 2.555 & 0.42 & 2.61 \\
\hline
\end{tabular}


Table 3: Correlation coefficients between diel $\mathrm{CO}_{2}$ and $\mathrm{CH}_{4}$ diffusion flux and the main environmental factors.

\begin{tabular}{|c|c|c|c|c|c|c|c|c|c|c|c|c|c|c|}
\hline & $\mathrm{Ta}$ & $\mathrm{Pa}$ & Swi & li & DOs & $\mathrm{DOb}$ & $\mathrm{pH}-\mathrm{s}$ & $\mathrm{pH}-\mathrm{b}$ & Ts & $\mathrm{Tb}$ & Diffusive- $\mathrm{CH}_{4}$ & Diffusive- $\mathrm{CO}_{2}$ & Chl-aSur & Chl-aBot \\
\hline Diffusive- $\mathrm{CH}_{4}$ & 0.25 & 0.01 & -0.04 & 0.20 & $\begin{array}{c}.344 \\
*\end{array}$ & -0.02 & $\begin{array}{c}-.417 \\
*\end{array}$ & $\begin{array}{c}.454 \\
* *\end{array}$ & $\begin{array}{c}.435 \\
\star *\end{array}$ & $\begin{array}{c}.389 \\
* *\end{array}$ & 1.00 & $\begin{array}{c}-.289 \\
*\end{array}$ & $\begin{array}{c}.304 \\
*\end{array}$ & $\begin{array}{c}.560 \\
\star *\end{array}$ \\
\hline Diffusive- $\mathrm{CO}_{2}$ & $\begin{array}{c}-.904 \\
\star \star\end{array}$ & $\begin{array}{c}.588 \\
\star \star\end{array}$ & -0.26 & $\begin{array}{c}-.443 \\
\star \star\end{array}$ & $\begin{array}{c}-.856 \\
\star \star\end{array}$ & $\begin{array}{c}-.290 \\
\star\end{array}$ & 0.09 & -0.13 & $\begin{array}{c}-.761 \\
\star *\end{array}$ & $\begin{array}{c}-.738 \\
\star \star\end{array}$ & $\begin{array}{c}-.289 \\
\star\end{array}$ & 1.00 & $\begin{array}{c}-.610 \\
\star *\end{array}$ & $\begin{array}{c}-.749 \\
\star \star\end{array}$ \\
\hline
\end{tabular}

**. Correlation is significant at the 0.01 level (2-tailed); ${ }^{*}$. Correlation is significant at the 0.05 level (2-tailed).

bubbles in the shallow eutrophic pond. However, bubble emissions of $\mathrm{CO}_{2}$ only accounted for $3.0 \%$ of the total, which showed that the ebullition had no significance in the release of $\mathrm{CO}_{2}$ from the pond. The result verifies that ebullition does not make a significant contribution to the release of $\mathrm{CO}_{2}$ from shallow eutrophic freshwater systems to the atmosphere, in contrast to the situation for $\mathrm{CH}_{4}$ where ebullition from them was significant [19]. The phenomenon was also observed in Petit Saut reservoir, where gas bubbles contained 50 to $80 \% \mathrm{CH}_{4}$ with few amounts $(<1 \%)$ of $\mathrm{CO}_{2}[16]$. In the small hypertrophic freshwater Priest Pot, most $\mathrm{CH}_{4}(96 \%)$ was also lost by ebullition, and most $\mathrm{CO}_{2}$ (99\%) by diffusive processes [33]. The ebullition $\mathrm{CH}_{4}$ efflux was $593.42 \mathrm{mg} \bullet \mathrm{m}^{-2} \bullet \mathrm{d}^{-1}$, which is much bigger than reported lakes, reservoirs and ponds except that from the exposed Reservoir Lokka (seasonal average up to $656 \mathrm{mg} \cdot \mathrm{m}^{-2} \bullet \mathrm{d}^{-1}$ ) [34].

\section{Discussion}

\section{Diel $\mathrm{CO}_{2}$ and $\mathrm{CH}_{4}$ diffusion flux}

Diel $\mathrm{CO}_{2}$ diffusion flux during the observing period was significantly positively correlated to the air pressure, and negatively correlated to the air temperature, intensity of illumination, DO in surface water, surface and bottom water temperature, and Chl-a in surface and bottom water (Table 3).

It's well known that the diel-scale inner coherence between air pressure, air temperature, water temperature and intensity of illumination, which results from the solar irradiation and the earth's evolution. Chl-a in surface water corresponded to the changing intensity of illumination with an alternative of photosynthesis and respiration. During the day when the rate of photosynthesis exceeds that of respiration, $\mathrm{CO}_{2}$ is consumed and $\mathrm{O}_{2}$ is produced. At night, in the absence of photosynthesis, respiration consumes $\mathrm{O}_{2}$ and produces $\mathrm{CO}_{2}$ [15]. Thus, significant correlations between the $\mathrm{CO}_{2}$ diffusion flux and the Chl-a and DO in surface water were observed here.

\section{Diel $\mathrm{CH}_{4}$ ebullition flux}

No apparent time series regularity was found about changes of the diel ebullition $\mathrm{CH}_{4}$ and $\mathrm{CO}_{2}$ flux. $\mathrm{CH}_{4}$ bubbled very frequently during the two days' field observing, and $\mathrm{CH}_{4}$ ebullition occurred in 44 of all 48 monitored segmentations (91.67\%). An especially big $\mathrm{CH}_{4}$ bubbling event occurred at approximately 21:00 on July 23, 2013, which resulted in an abrupt increase of $\mathrm{CH}_{4}$ concentration in the chamber from 6.64 to $539.93 \mathrm{ppm}$ and the maximum bubble flux of $424.28 \mathrm{mg} \bullet \mathrm{m}^{-2} \bullet \mathrm{h}^{-1}$. All other ebullition $\mathrm{CH}_{4}$ fluxes were lower than $85.0 \mathrm{mg} \cdot \mathrm{m}^{-2} \cdot \mathrm{h}^{-1}$ (Figure 3), and mainly located at $20-10$ and $<5 \mathrm{mg} \bullet \mathrm{m}$ ${ }^{2} \cdot h^{-1}$. Around $40.91 \%$ and $59.09 \%$ of total $\mathrm{CH}_{4}$ flux was emitted in the first and second day respectively. $\mathrm{CH}_{4}$ bubbling fluxes within $25 \%$ big rate accounted for $81.75 \%$ and the biggest $\mathrm{CH}_{4}$ bubbling event accounted for $35.75 \%$ of the two days' whole bubbling $\mathrm{CH}_{4}$ emission. This showed that ebullition was highly variable, and $\mathrm{CH}_{4}$ ebullition fluxes measured by the chambers in a short time might underestimate real values severely. Otherwise, gas fluxes emitted during daytime

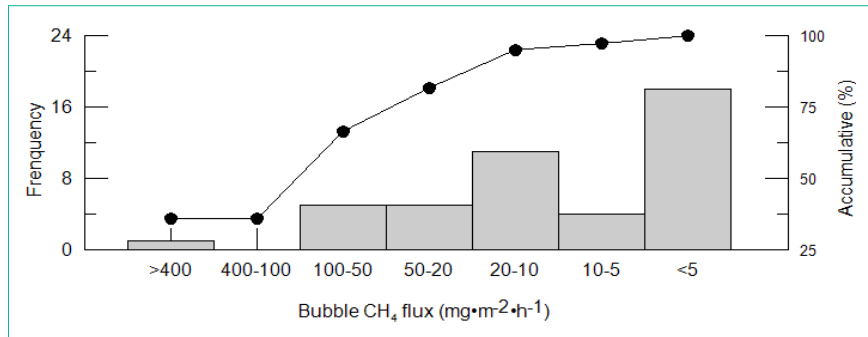

Figure 3: Frequency distribution of diel bubble $\mathrm{CH}_{4}$ flux during July 22-24, 2011.

were much lower than those during nighttime except diffusive $\mathrm{CH}_{4}$ flux (Figure 4). So, it's necessary to extend monitoring time in frequent and episodic bubbling water system to acquire more exact gas fluxes.

The diel $\mathrm{CH}_{4}$ flux was only significantly positively correlated to the DO in the bottom water $(\mathrm{r}=0.336, \mathrm{p}<0.05, \mathrm{~N}=48)$, which might indicate that $\mathrm{CH}_{4}$ was effectively oxidized by $\mathrm{O}_{2}$. Although part $\mathrm{CH}_{4}$ was consumed, $\mathrm{CH}_{4}$ efflux was still high owing to the high $\mathrm{CH}_{4}$ production resulted from high TOC content in sediments.

\section{C cycling mode of tropic shallow eutrophied impoundments}

Overall, the growth of microalgae populations depends on three abiotic factors: available light, temperature, and level of nutrients such as nitrogen, phosphorus, and silicate (for diatoms) [35]. The present pond during monitoring periods satisfied all these three conditions. The good weather condition and the temperature of around $30{ }^{\circ} \mathrm{C}$ were favorable to alga growth $[36,37]$. In case of many algae, maximal

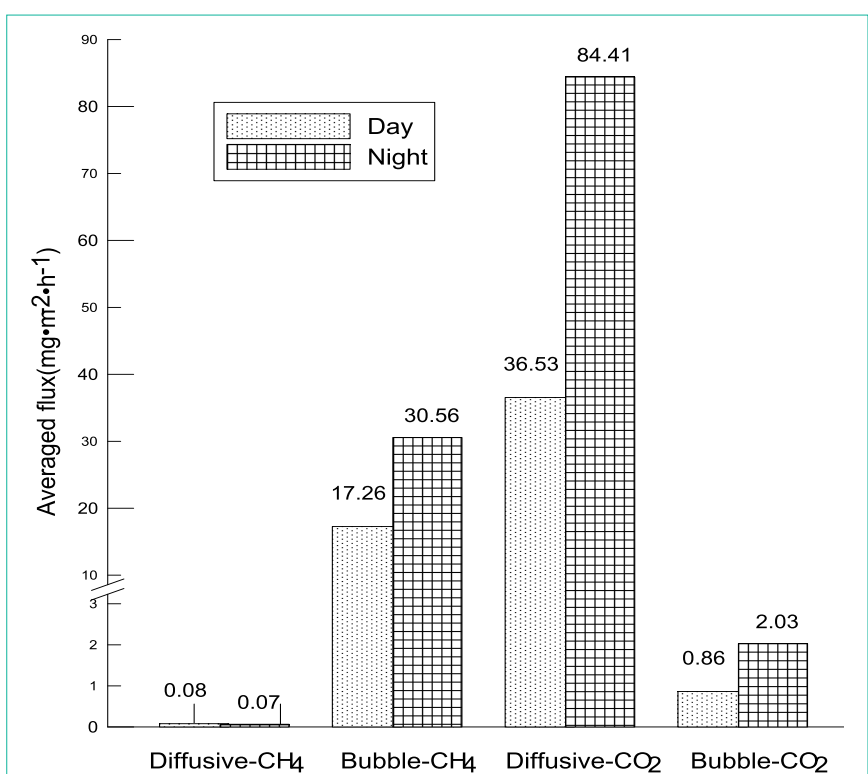

Figure 4: Comparison of gas fluxes between daytime (9:00-21:00) and nighttime (21:00-9:00) 
growth rate are observed at optimum temperatures between 28 and $35^{\circ}[38,39] .30^{\circ} \mathrm{C}$ had the best growth rates for both Scenedesmus $s p$. and Chlorella $[40,41]$, which almost accorded with those observed here. The total nitrogen and phosphorus concentrations in waters are about 0.067 and $0.020 \mathrm{mg} / \mathrm{L}$ respectively. Nutrient loading increases autochthonous primary production in lakes, promoting oxygen consumption and anaerobic decomposition in the sediments [34].

Water mixing in the pond was well, and no vertical temperature stratification occurred. Sediments temperature during the observation was high and proximate to the surface water temperature, which could increase numbers of methanogenic bacteria and rates of methanogenesis [42,43].

Humans now strongly influence almost every major aquatic ecosystem, and their activities have dramatically altered the fluxes of growth-limiting nutrients from the landscape to receiving waters. On a global basis, strong correlations have been demonstrated between total phosphorus inputs and phytoplankton production in freshwaters, and between total nitrogen input and phytoplankton production in estuarine and marine waters [44]. Eutrophication causes predictable increases in the biomass of algae in lakes and reservoirs; streams and rivers; wetlands; and coastal marine ecosystems. Consistent and predictable Eutrophication-caused increases in algal blooms have been reported worldwide, which is a global problem [45-50]

Here, the $\mathrm{CH}_{4}$ flux across the water-air interface of the pond was $595.20 \mathrm{mg} \bullet \mathrm{m}^{-2} \bullet \mathrm{d}^{-1}$, which equals $\mathrm{CO}_{2}$ flux of $14880.0 \mathrm{mg} \bullet \mathrm{m}^{-2} \bullet \mathrm{d}^{-1}$ by multiplying its global warming potential of 25 over a time horizon of $100 \mathrm{yr}$ [51]. Thus, the small pond added $35.712 \mathrm{~kg} / \mathrm{d} \mathrm{CO}_{2}$ emission by transferring $\mathrm{CO}_{2}$ to $\mathrm{CH}_{4}$ in the summer. In eutrophic Reservoir Lokka, the relatively high $\mathrm{CH}_{4}$ emissions were also primarily associated with the anaerobic decomposition of autochthonous, labile organic matter, rather than with decomposition of flooded old peat deposits [52]. Anoxia in eutrophic lakes favoring the $\mathrm{CH}_{4}$ production is the major contributor to the atmospheric consequences of water Eutrophication [53].

Tropic eutrophic ponds satisfy all these three conditions (available light, temperature, and level of nutrients) to the growth of microalgae populations. Nutrient loading and anoxia in eutrophic lakes also promote oxygen consumption and anaerobic decomposition in the sediments, and together with high temperature favor the $\mathrm{CH}_{4}$ production. Tropic shallow impoundments may serve as plants producing greenhouse gases by transferring $\mathrm{CO}_{2}$ to $\mathrm{CH}_{4}$ in the summer.

\section{Acknowledgment}

This work was sponsored by National Science Foundation of China (No. 41273110, 51079163), and State Key Laboratory of Loess and Quaternary Geology, Institute of Earth Environment, Chinese Academy of Sciences.

\section{Author Contributions}

The manuscript was written through contributions of all authors. All authors have given approval to the final version of the manuscript.

\section{References}

1. Barros N, Cole JJ, Tranvik LJ, Prairie YT, Bastviken D, Huszar VLM, et al. Carbon emission from hydroelectric reservoirs linked to reservoir age and latitude. Nature Geosci. 2011; 4: 593-596.
2. Bastviken D, Cole JJ, Pace ML, Van de Bogert MC. Fates of methane from different lake habitats: Connecting whole-lake budgets and $\mathrm{CH} 4$ emissions. Journal of Geophysical Research. 2008; 113: G02024.

3. Battin TJ, Luyssaert S, Kaplan LA, Aufdenkampe AK, Richter A, Tranvik LJ. The boundless carbon cycle. Nature Geosci. 2009; 2: 598-600.

4. Downing JA, Prairie YT, Cole JJ, Duarte CM, Tranvik LJ, Striegl RG, et al. The global abundance and size distribution of lakes, ponds, and impoundments. Limnology and Oceanography Methods. 2006; 51: 2388-2397.

5. Grossart HP, Frindte K, Dziallas C, Eckert W, Tang KW. Microbial methane production in oxygenated water column of an oligotrophic lake. Proc Natl Acad Sci U S A. 2011; 108: 19657-19661.

6. Jacinthe PA, Filippelli GM, Tedesco LP, Raftis R. Carbon storage and greenhouse gases emission from a fluvial reservoir in an agricultural landscape. Catena. 2012; 94: 53-63.

7. Whitfield CJ, Aherne J, Baulch HM. Controls on greenhouse gas concentrations in polymictic headwater lakes in Ireland. Sci Total Environ. 2011; 410-411: 217-25.

8. Xiao S, Liu D, Wang Y, Yang Z, Chen W. Temporal variation of methane flux from Xiangxi Bay of the Three Gorges Reservoir. Sci Rep. 2013; 3: 2500.

9. Xiao S, Wang Y, Liu D, Yang Z, Lei D, Zhang C. Diel and seasonal variation of methane and carbon dioxide fluxes at site Guojiaba, the Three Gorges Reservoir. J Environ Sci (China). 2013; 25: 2065-2071.

10. Yang L, Lu F, Wang X, Duan X, Song W, Sun B, et al. Spatial and seasonal variability of diffusive methane emissions from the Three Gorges Reservoir. Journal of Geophysical Research: Biogeosciences. 2013.

11. Kortelainen P, Rantakari M, Huttunen JT, Mattsson T, Alm J. Sediment respiration and lake trophic state are important predictors of large $\mathrm{CO} 2$ evasion from small boreal lakes. Glob. Change Biol. 2006; 12: 1554-1567.

12. Repo ME, Huttunen JT, Naumov AV, Chichulin AV, Lapshina ED, Bleuten W, et al. Release of $\mathrm{CO} 2$ and $\mathrm{CH} 4$ from small wetland lakes in western Siberia. Tellus B. 2007; 59: 788-796.

13. Riera JL, Schindler JE, Kratz TK. Seasonal dynamics of carbon dioxide and methane in two clear-water lakes and two bog lakes in northern Wisconsin, USA. Canadian Journal of Fisheries and Aquatic Sciences. 1999; 56: 265274.

14. Bubier J, Moore T, Savage K, Crill P. A comparison of methane flux in a boreal landscape between a dry and a wet year. Global Biogeochem. Cycles. 2005; 19.

15. Nimick DA, Gammons $\mathrm{CH}$, Parker SR. Diel biogeochemical processes and their effect on the aqueous chemistry of streams: A review. Chemical Geology. 2011; 283: 3-17.

16. Abril G, Guerin F, Richard S, Delmas R, Galy-Lacaux C, Gosse P, et al Carbon dioxide and methane emissions and the carbon budget of a 10-years old tropical reservoir (Petit-Saut, French Guiana). Global Biogeochem. Cycles. 2005; 19: GB4007.

17. Duchemin E. Lucotte M, Canuel R, Soumis N. First assessment of methane and carbon dioxide emissions from shallow and deep zones of boreal reservoirs upon ice break-up. Lakes \& Reservoirs: Research \& Management. $2006 ; 11 ; 9-19$.

18. Huttunen JT, Alm J, Saarijärvi E, Lappalainen KM, Silvola J, Martikainen PJ. Contribution of winter to the annual $\mathrm{CH} 4$ emission from a eutrophied boreal lake. Chemosphere. 2003; 50: 247-250.

19. Huttunen JT, Lappalainen KM, Saarijärvi E, Väsänen T, Martikainen PJ. A novel sediment gas sampler and a subsurface gas collector used for measurement of the ebullition of methane and carbon dioxide from a eutrophied lake. Sci Total Environ. 2001; 266: 153-158.

20. Xing Y, Xie P, Yang H, Ni L, Wang Y, Rong K. Methane and carbon dioxide fluxes from a shallow hypereutrophic subtropical Lake in China. Atmospheric Environment. 2005; 39: 5532-5540.

21. Zhang Y, Ding W. Diel methane emissions in stands of Spartina alterniflora and Suaeda salsa from a coastal salt marsh. Aquatic Botany. 2011; 95: 262267. 
22. Wang XF, Wei FS, Qi WQ. Monitoring and Analysis Methods of Wate and Wastewater, $4^{\text {th }}$ edn. China Environmental Science Press, Beijing (in Chinese). 2002.

23. Johnson KM, Hughes JE, Donaghay PL, Sieburth JM. Bottle-calibration static head space method for the determination of methane dissolved in seawater. Analytical Chemistry. 1990; 62: 2408-2412.

24. Eugster W, Pluss P. A fault-tolerant eddy covariance system for measuring CH4 fluxes. Agricultural and Forest Meteorology. 2010; 150: 841-851.

25. Hendriks DMD, Dolman AJ, van der Molen MK, van Huissteden J. A compact and stable eddy covariance set-up for methane measurements using off-axis integrated cavity output spectroscopy. Atmos. Chem. Phys. 2008; 8: 431-443.

26. Hendriks DMD, van Huissteden J, Dolman AJ. Multi-technique assessment of spatial and temporal variability of methane fluxes in a peat meadow. Agricultural and Forest Meteorology. 2010; 150: 757-774.

27. Herbst M, Friborg T, Ringgaard R, Soegaard $H$. Interpreting the variations in atmospheric methane fluxes observed above a restored wetland. Agricultural and Forest Meteorology. 2011; 151: 841-853.

28. Schroth MH, Eugster W, Gómez KE, Gonzalez-Gil G, Niklaus PA, Oester P. Above- and below-ground methane fluxes and methanotrophic activity in a landfill-cover soil. Waste Manag. 2012; 32: 879-889.

29. Lambert M, Frechette J. Analytical techniques for measuring fluxes of $\mathrm{CO} 2$ and $\mathrm{CH} 4$ from hydroelectric reservoirs and natural water bodies. In: Tremblay A, Varfalvy L, Roehm C, editors, Greenhouse Gas Emissions? Fluxes and Processes: Hydroelectric Reservoirs and Natural Environments. Springer, Berlin. 2005; 37-60.

30. Sellers P, Raymond Hesslein H, Kelly CA. Continuous measurement of $\mathrm{CO} 2$ for estimation of air-water fluxes in lakes: An in situ technique. Limnol. Oceanogr. 1995; 40: 575-581.

31. Yang L, Lu F, Wang X, Duan X, Song W, Sun B, et al. Spatial and seasonal variability of diffusive methane emissions from the Three Gorges Reservoir. Journal of Geophysical Research: Biogeosciences. 2013; 118: 471-481.

32. Delsontro T, McGinnis DF, Sobek S, Ostrovsky I, Wehrli B. Extreme methane emissions from a Swiss hydropower reservoir: contribution from bubbling sediments. Environ Sci Technol. 2010; 44: 2419-2425.

33. Casper P, Maberly SC, Hall GH, Finlay PJ. Fluxes of methane and carbon dioxide from a small productive lake to the atmosphere. Biogeochemistry. 2000; 49: 1-19.

34. Huttunen JT, Alm J, Liikanen A, Juutinen S, Larmola T, Hammar T, Silvola J. Fluxes of methane, carbon dioxide and nitrous oxide in boreal lakes and potential anthropogenic effects on the aquatic greenhouse gas emissions. Chemosphere. 2003; 52: 609-621.

35. Bouterfas R, Belkoura M, Dauta A. The effects of irradiance and photoperiod on the growth rate of three freshwater green algae isolated from a eutrophic lake. Limnetica. 2006; 25: 647-656.

36. Necchi Jr O, Branco CCZ, Branco LHZ. Distribution of Rhodophyta in streams from São Paulo State, southeastern Brazil. Archiv für Hydrobiologie. 1999; 147: 73-89.

37. Necchi O, Zucchi MR. Photosynthetic performance of freshwater Rhodophyta in response to temperature, irradiance, $\mathrm{pH}$ and diurnal rhythm. Phycological Research. 2001; 49: 305-318

38. Bouterfas R, Belkoura M, Dauta A. Light and temperature effects on the growth rate of three freshwater [2pt] algae isolated from a eutrophic lake. Hydrobiologia. 2002; 489: 207-217.
39. Soeder CJ, Hegewald E, Fiolitakis E, Grobbelaar JU. Temperature dependence of population growth in a green microalga: thermodynamic characteristics of growth intensity and the influence of cell concentration. Zeitschrift fur Naturforschung A: Journal of Physical Sciences. 1985; 40: $227-$ 233.

40. Cassidy KO. Evaluating Algal Growth at Different Temperatures, Biosystems and Agricultural Engineering. University of Kentucky. 2011.

41. Chinnasamy S, Ramakrishnan B, Bhatnagar A, Das KC. Biomass production potential of a wastewater alga Chlorella vulgaris ARC 1 under elevated levels of COâ,,and temperature. Int J Mol Sci. 2009; 10: 518-532.

42. Duc N, Crill P, Bastviken D. Implications of temperature and sediment characteristics on methane formation and oxidation in lake sediments. Biogeochemistry. 2010; 100: 185-196.

43. Kankaala P, Kaki T, Makela S, Ojala A, Pajunen H, Arvola L. Methane efflux in relation to plant biomass and sediment characteristics in stands of three common emergent macrophytes in boreal mesoeutrophic lakes. Global Change Biology. 2005; 11: 145-153.

44. Anderson D, Glibert P, Burkholder J. Harmful algal blooms and eutrophication: Nutrient sources, composition, and consequences. Estuaries. 2002; 25: $704-$ 726.

45. Davis JR, Koop K. Eutrophication in Australian Rivers, Reservoirs and Estuaries - A Southern Hemisphere Perspective on the Science and its Implications. Hydrobiologia. 2006; 559: 23-76.

46. Jin $X, X u Q$, Huang C. Current status and future tendency of Lake Eutrophication in China. Science in China Series C: Life Sciences. 2005; 48 : 948-954.

47. Kim B, Park JH, Hwang G, Jun MS, Choi K. Eutrophication of reservoirs in South Korea. Limnology. 2001; 2: 223-229.

48. Smith VH. Eutrophication of freshwater and coastal marine ecosystems: a global problem. Environ Sci Pollut Res Int. 2003; 10: 126-139.

49. Von Sperling E, Da Silva Ferreira AC, Nunes Ludolf Gomes L. Comparative eutrophication development in two Brazilian water supply reservoirs with respect to nutrient concentrations and bacteria growth. Desalination. 2008; 226: 169-174.

50. Yang J, Yu X, Liu L, Zhang W, Guo P. Algae community and trophic state of subtropical reservoirs in southeast Fujian, China. Environ Sci Pollut Res Int. 2012; 19: 1432-1442.

51. Meehl GA, Stocker TF, Collinds WD, Friedlingstein P, Gaye AT, Gregory JM, et al. Global climate Projections. In: Solomon S, Qin D, Manning M, editors. Climate Change 2007: The Physical Science Basis. Contribution of Working Group I to the Fourth Assessment Report of the Intergovernmental Panel on Climate Change, Cambridge University Press, Cambridge, United Kingdom and New York, NY, USA. 2007.

52. Huttunen JT, Vaisanen TS, Heikkikinen M, Hellsten S, Nykänen H, Nenonen $\mathrm{O}$, et al. Fluxes of $\mathrm{CH} 4, \mathrm{CO} 2$, and $\mathrm{N} 2 \mathrm{O}$ in hydroelectric reservoirs Lokka and Porttipahta in the northern boreal zone in Finland. Global Biogeochemical Cycles. 2002; 16: 1-17.

53. Liikanen A, Martikainen PJ. Effect of ammonium and oxygen on methane and nitrous oxide fluxes across sediment-water interface in a eutrophic lake. Chemosphere. 2003; 52: 1287-1293.
Austin Biom and Biostat - Volume 1 Issue 2 - 2014

Submit your Manuscript | www.austinpublishinggroup.com

Xiao et al. () All rights are reserved
Citation: Xiao S, Liu W, Yang H, Liu D, Wang Y, Peng F, et al. Extreme Methane Bubbling Emissions from a Subtropical Shallow Eutrophic Pond. Austin Biom and Biostat. 2014;1(2): 6. 